
Dalam Kabupaten Siak

\title{
Oil Palm Farmer's Income Using a Combination of Organic and Non Organic Fertilizers in Sialang Palas Village Lubuk Dalam District Siak Regency
}

\author{
Diana Silfia Situmorang, Jum'atri Yusri, Yusmini \\ Corresponding Author: Diana Silfia Situmorang \\ Email: dianasitumorang3@gmail.com
}

Jurusan Agribisnis Fakultas Pertanian Universitas Riau, dianasitumorang3@gmail.com

\begin{abstract}
Abstrak
Berbagai upaya telah dilakukan pemerintah dalam pengembangan usaha dan peningkatan kesejahteraan petani kelapa sawit.Salah satu program yang dicanangkan pemerintah adalah program sistem integrasi sapi dan kelapa sawit (SISKA). Secara umum petani di Provinsi Riau menggunakan pupuk non organik sebagai input dalam pengusahaan perkebunan kelapa sawit. Namun dengan adanya program SISKA, petani kelapa sawit mulai mengaplikasikan pupuk organik hasil limbah ternak sapi terhadap kelapa sawit. Petani kelapa sawit yang telah mengaplikasikan pupuk organik atau tepatnya mengkombinasikan pupuk organik dengan pupuk non organik terdapat di Desa Sialang Palas Kecamatan Lubuk Dalam Kabupaten Siak.Pemakaian pupuk organik tersebut muncul sejak dikenalkannya program SISKA di Desa Sialang Palas pada tahun 2013. Penelitian ini bertujuan untuk mengetahui keragaan budidaya, produktivitas dan pendapatan petani kebun kelapa sawit yang mengkombinasikan pupuk organik dan non organik di Desa Sialang Palas Kecamatan Lubuk Dalam Kabupaten Siak. Metode penelitian yang digunakan adalah metode survei. Pengambilan sampel dilakukan dengan teknik simple random sampling. Analisis data yang digunakan adalah analisis deskriptif dan analisis usahatani. Analisis deskriptif digunakan untuk mendeskripsikan keragaan usahatani kelapa sawit di Desa Sialang Palas. Analisis usahatani meliputi analisis biaya, pendapatan dan efisiensi usahatani. Hasil penelitian menunjukkan bahwa pupuk yang diberikan terdiri dari kombinasi pupuk organik dan non organik dengan jumlah pemberian pupuk yaitu feses sapi $2.101 \mathrm{~kg} / \mathrm{ha} / \mathrm{tahun}$, urin sapi $700 \mathrm{~kg} / \mathrm{ha} /$ tahun, KCL 20,83 kg/ha/tahun, Dolomit 252,80 kg/ha/tahun dan Phonska 90,83 kg/ha/tahun. Produktivitasnya adalah $18.578 \mathrm{~kg} / \mathrm{ha} / \mathrm{tahun}$ dengan umur tanaman 32 tahun. Total biaya produksi Rp.7.717.345/ha/tahun yang terdiri dari biaya tetap Rp.1.364.333,56/ha/tahun dan biaya variabel Rp.6.353.012,42/ha/tahun. Pendapatan bersih yang diterima petani sebesar Rp.16.859.773/ha/tahun.
\end{abstract}

Kata Kunci: pupuk organik, kelapa sawit, produktivitas, pendapatan.

\begin{abstract}
Various efforts have been made by the government in business development and improving the welfare of oil palm farmers. One of the programs announced by the government is the cattle and oil palm integration system program (SISKA). In general, farmers in Riau Province use non -organic fertilizers as input in oil palm plantations. However, with the SISKA program, oil palm farmers began to apply organic fertilizer from cattle waste to oil palm. Oil palm farmers who have applied organic fertilizer or precisely combined organic fertilizer with non -organic fertilizer are found in Sialang Palas Village, Lubuk District, Siak Regency. The use of organic fertilizer has emerged since the introduction of the SISKA program in Sialang Palas Village in 2013. This study aims to determine cultivation, productivity and income of oil palm plantation farmers who combine organic and non -organic fertilizers in Sialang Palas Village, Lubuk Dalam District, Siak Regency. The research method used is the survey method. Sampling was done with a simple random sampling technique. The data analysis used is descriptive analysis and agricultural analysis. Descriptive analysis was used to describe the nature of oil palm farming in Sialang Palas Village. Farm business analysis includes business cost, income and efficiency analysis. The results showed that the fertilizer given consisted of a combination of organic and non-organic fertilizers with
\end{abstract}


the amount of fertilizer given that is cow feces 2,101 kg/ha/year, cow urine $700 \mathrm{~kg} / \mathrm{ha} /$ year, KCL $20.83 \mathrm{~kg} / \mathrm{ha} /$ year, Dolomite $252,80 \mathrm{~kg} / \mathrm{ha} /$ year and Phonska $90.83 \mathrm{~kg} / \mathrm{ha} /$ year. The productivity is 18,578 kg/ha/year with a plant age of 32 years. Total production cost Rp.7.717.345/ha/year which consists of fixed cost Rp.1.364.333.56/ha/year and variable cost Rp.6.353.012.42/ha/year. The net income received by farmers is $R p .16,859,773 /$ ha/year.

Keywords: organic fertilizer, oil palm, productivity, income

\section{Pendahuluan}

Perkebunan kelapa sawit memberikan kontribusi besar pada perekonomian masyarakat di Provinsi Riau. Setiap tahun terjadi kecendrungan peningkatan luas lahan yang berarti banyak pelaku ekonomi berinvestasi di perkebunan kelapa sawit baik itu perkebunan swasta maupun perkebunan rakyat. Berbagai upaya telah dilakukan pemerintah dalam pengembangan usaha dan peningkatan kesejahteraan petani kelapa sawit.Salah satu program yang dicanangkan pemerintah adalah program sistem integrasi sapi dan kelapa sawit (SISKA). Sistem integrasi sapi dan kelapa sawit merupakan salah satu cara efektif meningkatkan produktivitas. Manfaat langsung yang diperoleh petani dari mengintegrasikan sawit dengan sapi, yakni hijauan dan limbah tanaman sawit dapat dimanfaatkan untuk menambah kebutuhan pakan bagi sapi, sedangkan kotoran hewan ternak tersebut dapat dijadikan kompos untuk meningkatkan kesuburan tanaman kelapa sawit [1].

Pada prinsipnya pengembangan integrasi ternak ke dalam usahatani baik dalam tanaman pangan, tanaman hortikultura maupun tanaman perkebunan adalah mengusahakan ternak tanpa mengurangi produktivitas dan aktifitas tanaman [2]. Adanya integrasi ini diharapkan dapat meningkatkan produktivitas tanaman. Sehingga integrasi ternak dan tanaman mencapai sinergi yang saling menguntungkan (mutualism sinergicity) yang pada akhirnya membantu menurunkan biaya produksi (cost production).

Secara umum petani di Provinsi Riau menggunakan pupuk non organik sebagai input dalam pengusahaan perkebunan kelapa sawit. Namun dengan adanya program SISKA, petani kelapa sawit mulai mengaplikasikan pupuk organik hasil limbah ternak sapi terhadap kelapa sawit. Penggunaan pupuk organik perlu digalakkan mengingat penggunaan pupuk kimia secara berkelanjutan dapat menimbulkakn dampak negatif seperti kerusakan lingkungan. Akibat pemakaian pupuk non organik dalam jumlah di atas takaran yang digunakan selama ini sudah mulai memberikan dampak lingkungan yang negatif, seperti menurunnya kandungan bahan organik tanah, rentannya tanah terhadap erosi, menurunnya permeabilitas tanah serta menurunnya populasi mikroba tanah [3].Menyadari akan hal tersebut maka diperlukan usaha untuk meniadakan atau mengurangi cemaran bahan kimia kedalam tubuh manusia dan lingkungan melalui pengurangan pupuk non organik dan meningkatkan pemakaian pupuk organik. Pemberian bahan organik dapat memperbaiki sifat fisik, kimia dan biologi tanah serta merangsang pertumbuhan mikroorganisme di dalam tanah.Bahan organik tidak dapat menggantikan peran dari pupuk non organik sebagai pemasok hara, karena kandungan unsur hara dalam bahan organik relatif rendah, namun demikian bahan organik dapat meningkatkan efisiensi penggunaan pupuk non organik [4].Pupuk organik dapat mengefisienkan pupuk non organik (NPK) sekitar 25 sampai 50\%, walaupun sumbangan hara N, P, K dari pupuk organik relatif kecil sekitar 5-10\%, tergantung dari tingkat mineralisasi dari pupuk organik tersebut [5].

Petani kelapa sawit yang telah mengaplikasikan pupuk organik atau tepatnya mengkombinasikan pupuk organik dengan pupuk non organik terdapat di Desa Sialang Palas Kecamatan Lubuk Dalam Kabupaten Siak.Pemakaian pupuk organik tersebut muncul sejak dikenalkannya program SISKA di Desa Sialang Palas pada tahun 2013. Kombinasi pemakaian pupuk organik dan pupuk non organik selama proses produksi diharapkan tidak menurunkan produktivitas kelapa sawit dan pendapatan petani bisa meningkat sebagai penurunan jumlah biaya pemakain pupuk kimia.Kombinasi pupuk organik dan non organik akan mengurangi penggunaan pupuk non organik sebesar $70 \%$ dan menghemat pengeluaran pupuk sebesar $19,14 \%$ sehingga pendapatan petani meningkat [6]. Selanjutya penelitian [7] menyatakan bahwa pemberian pupuk organik memberikan dampak positif dalam upaya meningkatkan produksi kelapa sawit dan apabila pupuk organik di kombinasikan dengan pupuk non organik akan meningkatkan produksi sebesar 39-48\%. 
Tujuan dari penelitian ini adalah 1) mengetahui keragaan budidaya perkebunan kelapa sawit di Desa Sialang Palas dilihat dari pemakaian faktor produksi 2) mengetahui produktivitas dan pendapatan petani kelapa sawit yang mengkombinasikan pupuk organik dan non organik di Desa Sialang Palas Kecamatan Lubuk Dalam Kabupaten Siak.

\section{Metode Penelitian}

Penelitian ini dilaksanakan di Desa Sialang Palas Kecamatan Lubuk Dalam Kabupaten Siak. Penentuan lokasi dilakukan karena terdapat petani kelapa sawit yang mengkombinasikan pupuk organik dengan pupuk non organik sebagai input faktor produksi. Penelitian dilakukan pada bulan April 2018 sampai Maret 2019.Data yang digunakan adalah data primer terdiri dari penggunaan faktor produksi seperti tenaga kerja, herbisida populasi tanaman kelapa sawit, luas lahan, umur tanaman, harga jual TBS, total produksi TBS, dan alat usahatani. Penelitian ini menggunakan metode survei. Populasi penelitian adalah petani perkebunan kelapa sawit berjumlah 80 petani yang tergabung dalam empat kelompok tani di Desa Sialang Palas, dimana dalam kelompok tani tersebut terdapat dua model budidaya yaitu petani yang murni menggunakan pupuk organik dan petani yang mengkombinasikan pupuk organi dengan non organik. Sampel diambil secara simple random sampling sebanyak 30 orang.

Analisis data yang digunakan adalah analisis deskriptif dan analisis usahatani. Analisis deskriptif digunakan untuk mendeskripsikan keragaan usahatani kelapa sawit di Desa Sialang Palas.Analisis usahatani meliputi analisis biaya, pendapatan dan efisiensi usahatani. Biaya usahatani terdiri dari biaya tetap dan biaya variabel. Biaya tetap dalam penelitian ini meliputi biaya pajak bumi dan bangunan (PBB), upah tenaga kerja dalam keluarga (TKDK) dan biaya penyusutan alat yang terdiri dari egrek, gancu, fiber, parang babat, batu gosok, gerobak dan sprayer. Biaya variabel meliputi biaya pembelian pupuk, herbisida, dan upah tenaga kerjaluar keluarga (TKLK). Biaya usahatani dapat dirumuskan sebagai berikut:

dimana:

$$
\mathrm{TC}=\mathrm{TFC}+\mathrm{TVC}
$$

$\mathrm{TC}=$ total biaya $(\mathrm{Rp} / \mathrm{ha} / \mathrm{tahun})$

TFC =total biaya tetap $((\mathrm{PBB}, \mathrm{TKLK}$, penyusutan alat, $(\mathrm{Rp} / \mathrm{ha} / \mathrm{tahun})$

TVC $=$ total biaya variabel $(($ pupuk, herbisida, TKLK $(\mathrm{Rp} / \mathrm{ha} / \mathrm{tahun}))$.

Metode penyusutan alat digunakan metode garis lurus, dimana beban penyusutan dihitung sama besarnya setiap tahun. Harga nilai beli alat berdasarkan harga beli oleh petani dan nilai alat diasumsikan 20\% dari nilai beli. Metode penyusutan dirumuskan sebagai berikut [8]:

dimana:

$$
\mathrm{D}=\frac{\mathrm{NB}-\mathrm{NS}}{\mathrm{UE}}
$$

$$
\begin{array}{ll}
\mathrm{D} & =\text { nilai penyusutan alat }(\mathrm{Rp} / \mathrm{unit} / \mathrm{tahun}) \\
\mathrm{NB} & =\text { nilai beli alat }(\mathrm{Rp} / \mathrm{unit}) \\
\mathrm{NS} & =\text { nilai sisa }((20 \% \text { nilai beli (Rp/unit)) } \\
\mathrm{UE} & =\text { umur ekonomis (tahun) }
\end{array}
$$

Penerimaan pada usahatani kelapa sawit merupakan hasil perkalian antara produksi TBS dengan harga jual TBS selama periode April 2018 sampai dengan Maret 2019. Analisis penerimaan dapat dirumuskan sebagai berikut [8]:

dimana:

$$
\mathrm{TR}=\mathrm{Y} . \mathrm{P}
$$

$$
\begin{array}{ll}
\mathrm{TR} & =\text { total penerimaan }(\mathrm{Rp} / \mathrm{ha} / \mathrm{tahun}) \\
\mathrm{Y} & =\text { produksi TBS }(\mathrm{kg} / \mathrm{ha} / \mathrm{tahun}) \\
\mathrm{P} & =\text { harga jual TBS }(\mathrm{Rp} / \mathrm{kg})
\end{array}
$$


Pendapatan bersih yang diterima petani adalah selisih penerimaan terhadap total biaya, dengan rumus sebagai berikut [8]:

dimana:

$$
\pi=\mathrm{TR}-\mathrm{TC}
$$

$\pi=$ pendapatan $(\mathrm{Rp} / \mathrm{ha} / \mathrm{tahun})$

$\mathrm{TR}=$ total penerimaan $(\mathrm{Rp} / \mathrm{ha} / \mathrm{tahun})$

$\mathrm{TC}=$ biaya produksi $(\mathrm{Rp} / \mathrm{ha} / \mathrm{tahun})$

Analisis efisiensi menggunakan analisis Revenue Cost of Ratio (RCR). Revenue Cost of Ratio adalah suatu pengujian analisa kelayakan dengan perbandingan antara total pendapatan dengan total biaya yang dikeluarkan. Kriteria yang digunakan dalam analisis ini adlah apabila nilai R/C > 1 maka usahatani dikatakan untung dan layak untuk diusahakan, karena besarnya pendapatan lebih besar dari besarnya biaya yang dikeluarkan, dan sebaliknya. Perhitungan hasil analisis pendapatan dengan biaya $(\mathrm{R} / \mathrm{C})$ dapat dilihat sebagai berikut:

dimana:

$$
\mathrm{RCR}=\mathrm{TR} / \mathrm{TC}
$$

$$
\begin{aligned}
& \mathrm{RCR}=\text { efisiensi usahatani } \\
& \mathrm{TR}=\text { Pendapatan Kotor (Rp/ha/tahun) } \\
& \mathrm{TC}=\text { Biaya Produksi (Rp/ha/tahun) }
\end{aligned}
$$

\section{Hasil dan Pembahasan}

\section{Keragaan Usahatani Perkebunan Kelapa Sawit}

Awal mulanya pembukaan kebun kelapa sawit di Desa Sialang Palas dimulai dari kegiatan transmigrasi penduduk tahun 1986 dan disebut pola pertanian kelapa sawit inti-plasma (PIR).Pemerintah bekerjasama dengan PT. Perkebunan Nusantara V (PTPN V) dalam pembukaan lahan, penanaman sampai tanaman tersebut menghasilkan, setelah menghasilkan tanaman kelapa sawit dikembalikan kepada setiap petani tepatnya tahun 1995.Umur tanaman saat penelitian adalah 32 tahun dengan kondisi yang belum di replanting.Luas lahan kelapa sawit setiap petani adalah 2 ha, rata-rata terdapat 140 batang per hektar tanaman kelapa sawit jenis Marihat dengan jarak tanam $8 \mathrm{x}$ 9 meter.

Prinsip penerapan program SISKA adalah memanfaatkan kotoran sapiuntuk penghematan penggunaan pupuk kimia. Sebelum program SISKA dikenalkan di Desa Sialang Palas, petani kelapa sawit menggunakan pupuk kimia secara keseluruhan, namun dengan masuknya program SISKA pada tahun 2013, petani kelapa sawit di Desa Sialang Palas mulai memberikan tambahan pupuk organik berupa feses dan urin sapi yang telah mendapat perlakuan terlebih dahulu.

Petani mengkombinasikan pupuk organik dan pupuk non organik pada perkebunan kelapa sawit yang dikelola.Pupuk organik yang digunakan adalah hasil limbah ternak sapi berupa feses dan urin sapi.Penggunaan feses sapi untuk satu pokok kelapa sawit adalah $15 \mathrm{~kg} /$ pokok/tahun, sedangkan urin sapi sebanyak 5 1/pokok/tahun. Anjuran pemupukan yang dianjurkan penyuluh pertanian adalah feses $30 \mathrm{~kg} /$ pokok/lahan dan urin 10 1/pokok/tahun. Aplikasi pupuk organik dilakukan 1-2 kali setahun.Rata-rata penggunaan pupuk organik dapat dilihat pada Tabel 1.

\begin{tabular}{clr}
\multicolumn{4}{c}{ Tabel 1. Rata-rata Penggunaan Pupuk Organik } \\
\hline No & \multicolumn{1}{c}{ Jenis Pupuk } & Jumlah $(\mathrm{kg} / \mathrm{ha} / \mathrm{tahun})$ \\
\hline 1 & Urin (l/ha) & 700.00 \\
2 & Feses (kg/ha) & $2,101.00$ \\
\hline
\end{tabular}

Pupuk non organik yang digunakan adalah KCL, Dolomit dan Phonska.Petani yang menggunakan pupuk KCL sedikit dan cenderung mengganti kebutuhan pupuk utama dengan Phonska.Pupuk Phonska adalah pupuk majemuk NPK yang mengandung 3 macam unsur utama yaitu Nitrogen, Fosfat, Kalium dan Sulfur. Pupuk majemuk banyak dipilih petani karena lebih praktis dan kandungan unsur hara makro tanaman dapat terpenuhi [9].Rata-rata penggunaan pupuk untuk satu pokok kelapa sawit adalah KCL $1 \mathrm{~kg} /$ pokok/tahun, Dolomit $2 \mathrm{~kg} /$ pokok/tahun dan Phonska 1,25 $\mathrm{kg} /$ pokok/tahun.Petani menggunakan tiga jenis pupuk non organik dan pemupukan dilakukan satu 
kali setahun per jenis pupuk non organik. Dosis dan rotasi pemupukan non organik tidak sesuai dengan anjuran pemupukan, dikarenakan petani telah mengkombinasikan nya dengan pupuk organik. Rata-rata penggunaan pupuk non organik pada kebun kelapa sawit di Desa Sialang Palas dapat dilihat pada Tabel 2.

Tabel 2. Anjuran Penggunaan Pupuk Non organik

\begin{tabular}{lccc}
\hline \multirow{3}{*}{ No } & \multirow{2}{c}{ Rekomendasi Pemupukan } \\
\cline { 3 - 4 } & Pupuk & Dosis & Rotasi \\
\cline { 3 - 4 } & & (kg/pokok) & 2.00 \\
1 & KCL & 3.00 & 2.00 \\
2 & Dolomit & 2.00 & 2.00 \\
3 & Phonska & 2.00 & \\
\hline
\end{tabular}

Pengendalian gulma oleh petani dilakukan untuk menjaga keefektifan pemupukan yang berpengaruh terhadap hasil tanaman.Pengendalian gulma yang dilakukan petani secara kimiawi dan mekanik.Pengendalian secara kimiawi seperti semprot piringan, semprot jalan pikul, semprot semak serta pengendalian alang-alang menggunakan herbisida yaitu Round-Up dan Gramaxon.Jumlah pemakaian Round-Up dan Gramaxon tidak berbeda jauh dan menurut petani herbisida tersebut yang cocok dan efektif digunakan pada lahan kelapa sawit di Desa Sialang Palas.Sementara itu, pengendalian gulma berbatang keras dilakukan secara mekanik menggunakan parang babat.

Tabel 3. Rata-Rata pemakaian herbisida

\begin{tabular}{ccrr}
\hline No & Jenis Herbisida & Jumlah (1/ha/tahun) & Persentase (\%) \\
\hline 1 & Round-Up & 1.74 & 49.57 \\
2 & Gramoxon & 1.77 & 50.43 \\
\hline & Jumlah & 3.51 & 100.00 \\
\hline
\end{tabular}

Pemakaian tenaga kerja meliputi kegiatan pemupukan, pengendalian gulma dan pemanenan.Tenaga kerja untuk setiap kegiatan berasal dari tenaga kerja dalam keluarga (TKDK) dan tenaga kerja luar keluarga (TKLK).Berdasarkan pengamatan, petani belum memperhitungkan biaya upah TKDK karena menganggap kegiatan yang dilakukan merupakan tanggung jawab yang dimiliki sebagai keluarga pelaku usaha.Sementara untuk upah TKLK dilakukan borongan.Umumnya petani mengunakan 2 orang tenaga kerja per kegiatan pada lahan 2 ha.

\section{Produksi dan Produktivitas Kelapa Sawit}

Menurut [10] tanaman kelapa sawit dapat di panen pada saat tanaman berumur tiga atau empat tahun. Produksi yang dihasilkan akan terus bertambah seiring bertambahnya umur dan akan mencapai produksi maksimalnya pada saat tanaman berumur 9-14 tahun, setelah itu produksi yang dihasilkan akan mulai menurun. Umur ekonomis tanaman kelapa sawit berkisar antara 25-26 tahun. Selain mempengaruhi produksi, umur tanaman kelapa sawit juga akan mempengaruhi produktivitas tanaman. Tingkat produktivitas tanaman kelapa sawit akan meningkat secara tajam dari umur tujuh tahun dan akan mencapai tingkat produktivitas maksimalnya pada umur lima belas tahun dan mulai menurun secara perlahan seiring dengan pertambahan umur tanaman. Produksi dan produktivitas kelapa sawit yang menggunakan dan tidak menggunakan pupuk organik di Desa Sialang Palas dapat dilihat pada Tabel 4.

Rata-rata produksi kelapa sawit per bulannya dengan nilai terendah adalah $1.471 \mathrm{~kg} / \mathrm{ha} / \mathrm{bulan}$ dan tertinggi $1.656 \mathrm{~kg} / \mathrm{ha} / \mathrm{bulan}$ dengan produktivitas kelapa sawit adalah $18.578 \mathrm{~kg} / \mathrm{ha} / \mathrm{tahun}$ pada umur 32 tahun. Jika dibandingkan dengan penelitian Supitriyani (2016) [11] yang menyatakan bahwa produktivitas kelapa sawit di Kecamatan Lubuk Dalam Provinsi Riau yaitu 25.905 kg/ha/tahun pada umur tanaman 26 tahun, maka produktivitas petani kelapa sawit responden lebih rendah dengan selisih $7.327 \mathrm{~kg} / \mathrm{ha} / \mathrm{tahun}$. Salah satu penyebab perbedaan produktivitas tersebut adalah umur tanaman kelapa sawit yang di teliti telah berada pada masa peremajaan (replanting) atau sudah berumur tua yaitu 32 tahun. Menurut petani kelapa sawit di Desa Sialang Palas, meskipun umur kelapa sawit sudah melewati umur ekonomis, kebun kelapa sawit tersebut masih menghasilkan 
produksi yang memberikan keuntungan atau penerimaan yang diterima petani masih lebih besar dari biaya yang dikeluarkan.

Tabel 4.Produksi dan Produktivitas Kelapa Sawit Periode April 2018 - Maret 2019

\begin{tabular}{lrr}
\hline & Periode & Harga (Rp) \\
\hline April & & 1,551 \\
Mei & 1,475 & 1,523 \\
Juni & 1,485 & 1,490 \\
Juli & 1,494 & 1,294 \\
Agustus & 1,577 & 1,310 \\
September & 1,601 & 1,180 \\
Oktober & 1,656 & 1,200 \\
November & 1,630 & 1,150 \\
Desember & 1,571 & 1,170 \\
Januari & 1,471 & 1,340 \\
Februari & 1,542 & 1,380 \\
Maret & 1,579 & 1,344 \\
\hline \multicolumn{2}{c}{ Produktivitas (kg/ha/tahun) } & 1,502 \\
\hline
\end{tabular}

\section{Biaya Usahatani}

Biaya usahatani adalah semua pengeluaran yang dipergunakan dalam suatu usahatani [8].Biaya usahatani terdiri dari biaya tetap dan biaya variable.Biaya tetap dalam penelitian ini meliputi biaya pajak bumi dan bangunan (PBB), upah tenaga kerja dalam keluarga (TKDK) serta penyusutan alat.Alat yang dipakai terdiri dari, egrek, gancu, fiber, parang babat, batu gosok, gerobak dan sprayer, sedangkan biaya variabel meliputi biaya pembelian pupuk, herbisida, dan upah tenaga kerja luar keluarga (TKLK).

\section{Biaya penyusutan Alat}

Alat-alat pertanian yang digunakan oleh petani memiliki nilai penyusutan menurut usia ekonomis, harga beli dan jumlah alat dari masing-masing petani.Rata-rata total biaya penyusutan alat petani kelapa sawit di Sialang Palas adalah Rp.370.153,78/ha/tahun.Biaya penyusutan tertinggi pada perkebunan kelapa sawit yang mengkombinasikan pupuk organik dan non organik di Desa Sialang Palas adalah biaya penyusutan fiber sebesar Rp.90.666,67/2ha/tahun atau 24,49\% dari total biaya penyusutan alat. Biaya penyusutan alat kebun kelapa sawit di Desa Sialang Palas dapat dilihat pada Tabel 5.

Tabel.5 Biaya Penyusutan Alat Kebun Kelapa Sawit

\begin{tabular}{clrrr}
\hline No & \multicolumn{1}{c}{ Alat } & UE (tahun) & Penyusutan (Rp/unit) & Persentase $(\%)$ \\
\hline 1 & Egrek & 3 & $60,177.78$ & 16.26 \\
2 & Gancu & 5 & $7,597.33$ & 2.05 \\
3 & Fiber & 5 & $90,666.67$ & 24.49 \\
4 & Parang babat & 5 & $12,746.67$ & 3.44 \\
5 & Batu gosok & 2 & $8,800.00$ & 2.38 \\
6 & Gerobak & 5 & $70,485.33$ & 19.04 \\
7 & Sprayer & 5 & $74,346.67$ & 20.09 \\
8 & Mesin rumput & 5 & $45,333.33$ & 12.25 \\
\hline & & & $370,153.78$ & 100.00 \\
\hline
\end{tabular}

\section{Pajak Bumi dan Bangunan (PBB)}

Pajak bumi dan bangunan menjadi biaya yang harus dikeluarkan petani karena penggunaan lahan yang ditanami kelapa sawit.Biaya pajak tersebut dikeluarkan oleh petani kepada pemerintah setiap tahunnya.Pajak lahan perlu dimasukkan kedalam perhitungan biaya karena meskipun nilainya sedikit namun termasuk biaya tetap yang wajib dikeluarkan oleh petani.Biaya PBB yang dikeluarkan tiap petani adalah Rp.35.000,00/ha/tahun. 


\section{Upah Tenaga Kerja}

Upah tenaga kerja pemupukan, pengendalian gulma, dan pemanenan di Desa Sialang Palas dilakukan dengan borongan.Upah tenaga kerja pemupukan yaitu Rp.10.000/sak, dimana semakin banyak jumlah pupuk yang digunakan maka upah yang dikeluarkan semakin tinggi.Upah tenaga kerja pengendalian gulma dan pemanenan secara berurutan yaitu Rp.800.000/ha dan Rp.140/kg. Rata-rata total upah tenaga kerja dalam keluarga (TKDK) kebun kelapa sawit di Desa Sialang Palas yaitu Rp.1.144.256,67/ha/tahun dan rata-rata total upah tenaga kerja luar keluarga (TKLK) adalah Rp.3.558.872,42/ha/thn.

Tabel 6. Rata-rata Upah Tenaga Kerja Pada Perkebunan Kelapa Sawit di Desa Sialang Palas

\begin{tabular}{lrr}
\hline \multirow{2}{*}{ Uraian } & \multicolumn{1}{c}{ Biaya (Rp/ha/tahun) } \\
\cline { 2 - 3 } & TKDK & \multicolumn{1}{c}{ TKLK } \\
\hline Pemupukan KCL & $2,083.34$ & $2,083.34$ \\
Pemupukan Dolomit & $17,840.00$ & $32,720.00$ \\
Pemupukan Phonska & $6,083.34$ & $12,083.34$ \\
Pemupukan urin & $69,950.00$ & $111,050.00$ \\
Pemupukan feses & $168,300.00$ & $279,900.00$ \\
Pengendalian gulma & $880,000.00$ & $373,333.33$ \\
Pemanenan & - & $2,747,702.42$ \\
\hline \multicolumn{1}{c}{ Jumlah } & $1,144,256.67$ & $3,558,872.42$ \\
\hline
\end{tabular}

Petani kelapa sawit di Desa Sialang Palas tidak menggunakan TKDK dalam kegiatan panen, namun menggunakan TKLK secara keseluruhan.Biaya tenaga kerja panen ditentukan oleh banyaknya produksi kelapa sawit, apabila jumlah produksi kelapa sawit tinggi maka upah tenaga kerja yang dikeluarkan juga tinggi.Dengan demikian, pengeluaran upah terbesar adalah upah TKLK kegiatan panenkelapa sawit sebesar Rp.2.747.702,42/ha/tahun.

\section{Total Biaya Usahatani}

Total biaya yang dikeluarkan selama satu tahun oleh petani kelapa sawit di Desa Sialang Palas adalah Rp.7.717.345,98/ha/tahun. TotalBiaya variabel merupakan penyumbang utama pada usahatani kelapa sawit di Desa Sialang Palas yaitu 82,32\% atau Rp.6.353.012,42/ha/tahun dari total biaya usahatani kelapa sawit. Tingginya biaya variabel tersebut dipengaruhi oleh frekuensi kegiatan, harga pembelian faktor produksi, dan volume masing-masing varibel yang digunakan seperti jumlah pupuk dan herbisida dimana kebutuhan faktor produksi tersebut akan berubah setiap waktu.

Tabel. 7. Total Biaya Kebun kelapa Sawit

\begin{tabular}{|c|c|c|c|}
\hline $\mathrm{No}$ & Jenis Biaya & Biaya (Rp/ha/tahun & Persentase $(\%)$ \\
\hline \multirow[t]{5}{*}{1} & Biaya Tetap & & \\
\hline & TKDK & $1,144,256.67$ & 14.83 \\
\hline & Penyusutan Alat & $185,076.89$ & 2.40 \\
\hline & PBB & $35,000.00$ & 0.45 \\
\hline & Sub Total & $1,364,333.56$ & 17.68 \\
\hline \multirow[t]{4}{*}{2} & Biaya Variabel & & \\
\hline & Pupuk & $2,575,473.34$ & 33.37 \\
\hline & Pestisida & $218,666.67$ & 2.83 \\
\hline & TKLK & $3,558,872.42$ & 46.12 \\
\hline \multicolumn{2}{|c|}{ Sub total } & $6,353,012.42$ & 82.32 \\
\hline & Total & $7,717,345.98$ & 100.00 \\
\hline
\end{tabular}

\section{Pendapatan Petani Kelapa Sawit}

Indikator keberhasilan suatu usahatani dapat dilihat dari besarnya pendapatan yang diterima oleh petani.Usahatani dikatakan menguntungkan apabila jumlah penerimaan yang diperoleh lebih besar dari biaya yang dikeluarkan.Pendapatan usahatani dalam penelitian ini terdiri dari pendapatan atas biaya total. 
Tabel 8.Rata-Rata Pendapatan Petani Kelapa Sawit di Desa Sialang Palas

\begin{tabular}{|c|c|c|}
\hline No & Deskripsi & Biaya (Rp/ha/tahun) \\
\hline 1 & Biaya Tetap & $1,364,333.56$ \\
\hline 2 & Biaya Variabel & $6,353,012.42$ \\
\hline 3 & Biaya Total & $7,717,345.98$ \\
\hline 4 & Penerimaan & $24,608,597.50$ \\
\hline 5 & Pendapatan Bersih & $16,891,251.52$ \\
\hline 6 & $\mathrm{RCR}$ & 3.19 \\
\hline
\end{tabular}

Pendapatan bersih yang diterima petani selama satu tahun sebesar Rp.16.891.251,52/ha/tahun. Nilai RCR usahatani kelapa sawit di Desa Sialang Palas adalah 3,19 untuk per hektar lahan kelapa sawit, artinya setiap satu rupiah yang dikeluarkan oleh petani menghasilkan keuntungan sebesar 2,19. Hal ini menunjukan bahwa usahatani kelapa sawit yang mengkombinasikan pupuk organik dan pupuk non organik menguntungkan dan layak diusahakan.

\section{Kesimpulan}

Keragaan usahatani kelapa sawit yang menggunakan pupuk organik di Desa Sialang Palas sebagai berikut: luas lahan rata-rata 2 ha per petani dengan umur tanaman pada saat penelitian ratarata 32 tahun. Jumlah pemakaian pupuk organik feses $2.101 \mathrm{~kg} / \mathrm{ha} /$ tahun dan urin 7001/ha/tahun. Jumlah pemakaian pupuk non organik diantaranya penggunaan KCL sebesar 20,84 kg/ha/tahun, Phonska sebesar 90,84 kg/ha/tahun, Dolomit sebesar 252,80 kg/ha/tahun.

Produktivitas kebun kelapa sawit yang mengkombinasikan pupuk organik dan non organik di Desa Sialang Palas pada umur tanaman 32 tahun sebesar $18.578 \mathrm{~kg} / \mathrm{ha} / \mathrm{tah}$ un. Produktivitas tersebut sudah mengalami penurunan dibanding produktivitas maksimal TBM kelapa sawit pada umur ekonomis, hal tersebut dikarenakan umur tanaman yang diteliti sudah pada fase peremajaan (replanting) atau sudah berumur tua. Rata-rata produktivitas kelapa sawit per bulannya dengan nilai terendah adalah $1.471 \mathrm{~kg} / \mathrm{ha} / \mathrm{bulan}$ dan tertinggi $1.656 \mathrm{~kg} / \mathrm{ha} / \mathrm{bulan}$.

Pendapatan bersih yang diterima oleh petani kelapa sawit yang menggunakan pupuk organik di Desa Sialang Palas sebesar Rp.16.891.251,52/ha/tahun dengan nilai RCR 3,19, sehingga usahatani kelapa sawit kombinasi pupuk organik dengan pupuk non organik menguntungkan dan layak diusahakan.

\section{Daftar Pustaka}

[1] Gusnar. 2014. Produktivitas Integrasi Kelapa Sawit dan Sapi di Labuhan Batu.BPP. Kecamatan Bilah Hilir. Labuhan Batu. Dikutip dari: Jurnal Agribisnis Sumatera Utara/Antara/Online. Diakses 15 Januari 2020.(Jurnal)

[2] Direktorat Jenderal Peternakan RI. 2011. Pedoman Umum Pengembangan Integrasi Ternak Sapi Tahun 2012. Direktorat Jenderal Peternakan Kementrian Pertanian Republik Indonesia. Jakarta.

[3] Herdiyanto D, Setiawan A. 2015. Upaya Peningkatan Kualitas Tanah Melalui Sosialisasi Pupuk Hayati, Pupuk Organik, dan Olah Tanah Konservasi di Desa Sukamanah dan Desa Nanggerang Kecamatan Cigalontang Kabupaten Tasikmalaya, Jurnal Aplikasi Ipteks Untuk Masyarakat, 4(1): 47-53. (Jurnal)

[4] Soedardjo, dan Mashuri. 2002. Peningkatan Produktivitas, Kualitas dan Efisiensi Sistem Produksi Tanaman Kacang-Kacangan dan Umbi-Umbian Menuju Ketahanan Pangan dan Agribisnis. Jurnal Penelitian, 2002(1): 360-371. (Jurnal)

[5] SiregarA.F, dan W. Hartatik. 2010. Aplikasi Pupuk Organik dalam Meningkatkan Efisiensi Pupuk Non organik pada Lahan Sawah.Seminar Nasional Sumberdaya Lahan Pertanian. Bogor. 30 November-1 Desember 2010.

[6] Marlina Y, Idqan Fahmi, Arif Satria. 2018. Customer Discovery of Biofertilizer Business (A Lesson from Pt PHN Experience), Jurnal Manajemen \& Agribisnis, 15(2): 107-117. (Jurnal)

[7] Bamualim A.M, F Madarisa, Y Pendra, E Mawardi, dan Asmak. 2015. Kajian Inovasi Integrasi Tanaman-Ternak Melalui Pemanfaatan Hasil Ikutan Tanaman Sawit Untuk Meningkatkan Produksi Sapi Lokal Sumatera Barat, Jurnal Peternakan Indonesia, 17(2): 1-11. (Jurnal) 
[8] Soekartawi. 2012. Analisis Usahatani. UI Press, Jakarta.

[9] Novizan.2002. Petunjuk Pemupukan yang Efektif.PT. Agromedia Pustaka. Jakarta.

[10] Pahan, I. 2008. Kelapa Sawit Manajemen Agribisnis Dari Hulu Hingga Hilir. Penebar Swadaya. Jakarta.

[11] Supitriani, D. 2017. Analisis Perbandingan Pendapatan Usaha Integrasi Sapi dan Kelapa Sawit Sistem Pemeliharaan Intensif dan Semi Intensif di Kecamatan Lubuk Dalam Kabupaten Siak. Skripsi (Tidak Dipublikasikan). Jurusan Agribisnis. Fakultas Pertanian. Universitas Riau. Pekanbaru.

[12] Fauzi, Y., 2007. Kelapa Sawit Budidaya, Pemanfaatan Hasil dan Limbah, Analisis Usaha dan Pemasaran. Penebar Swadaya. Jakarta. 